\title{
An Investigation of Undergraduate Students' Beliefs about Autonomous Language Learning
}

\section{Wiwat Orawiwatnakul}

Language Institute, Bangkok University, Thailand, wiwat.o@bu.ac.th

\section{Saovapa Wichadee}

Language Institute, Bangkok University, Thailand, saovapa.w@bu.ac.th

The concept of learner autonomy is now playing an important role in the language learning field. An emphasis is put on the new form of learning which enables learners to direct their own learning. This study aimed to examine how undergraduate students believed about autonomous language learning in a university setting and to find out whether some factors were related to their beliefs. A 5-point Likert scale questionnaire was employed to gather data from the firstyear students taking a fundamental English course in a private university. The findings revealed that on average, students had a high level of beliefs about autonomous language learning while language learning behaviors outside the class were at a moderate level. The relationships were found between beliefs of autonomous language learning and all factors comprising English proficiency, gender, attitudes towards studying English, and language learning behaviors outside the class. The findings highlight the need for increasing learning environments where responsibilities are shared between teachers and students.

Key Words: learning autonomy, language learning, autonomous learning, belief, undergraduate students

\section{INTRODUCTION}

Nowadays, strategies used to deliver knowledge are focused on the new form which enables learners to direct their own learning. "Autonomous learning" has become a term extensively used in education (Hedge, 2002), and its core concept, as defined by Holec (1996), means the ability to take charge of one's own learning. Lee (1998) explains that taking charge of one's own learning is the selection of learning contents and methods to achieve their learning goals. This implies that learners can work on their own pace and know what, when, why, how and where to learn. Learners have the power and right to learn for themselves (Smith, 2008). The autonomous learning capacity is found to be similar to that of Littlewood (1996) who defines it as the ability and willingness to assume learning responsibility. The ability, in particular, includes both the knowledge and skills for carrying out whatever choices the learners see appropriate for their 
learning. Willingness refers to the motivation and the confidence that the learners have for taking responsibilities in their learning. According to Gardner and Miller (1996), autonomous language learners will be able to initiate the planning and to implement their own learning program. They set themselves specific targets and goals and try to achieve these goals by taking opportunities both in and out of the classroom. This pushes learners move from the unconscious performance of a task to fully self-organized learning. Therefore, learning how to learn is a crucial and central component of all autonomous learning schemes (Little, 2007).

However, since the concept of learner autonomy emerged in western countries and was part of western culture, autonomous learning may not suit learners in other cultures. The issue of cultural appropriateness has been discussed in relation to independent language learning in Asia over the past decade since culture may be an obstacle to autonomous learning. The learning culture in the Asian countries seems to have a great impact on the development of learner autonomy as pointed out by Chan (2003) and Gan (2004). The kind of learning that opens the opportunities for learners to express their opinions, share ideas, and make decisions probably makes them feel uncomfortable. In the traditional classroom settings, teachers usually take control of classroom. They act as authoritative figures who are generally assumed to be knowledgeable and expected to transmit the knowledge to students; whereas, the learners were those who get the knowledge as much as they could from their teachers. A study conducted by Yildirim (2012) indicates that Indian students still believe that teacher has the greatest responsibility in class. Correcting grammar mistakes, ensuring accuracy, planning the course, setting the objectives of the course, deciding on the content, deciding on the activities, and evaluating the course were the basic issues mentioned by the participants as the aspects of language learning that the teacher has much more responsibility than the students. Many studies showed that learners still had traditional beliefs about teachers and their roles which affected the acceptance to take a role of self-organized learning (Cotterall, 1995; Sakai et al., 2008). Some researchers even identify that fostering of learner autonomy in Asian culture would be problematic (Lamb, 2004). For instance, Ho and Crookall (1995) claim that Chinese students would feel uncomfortable with any educational approach which required them to challenge the authority of the teacher, and Chinese teachers might likewise be reluctant to surrender control to their students. In autonomous learning practice, teachers should change their roles by letting students take main responsibilities in the learning process. It is necessary for both teachers and students to have the same understanding; otherwise, it is rather difficult to develop students' autonomous learning capacity in Asian settings.

Thailand, like other Asian countries, has been attempting to foster autonomous learning in educational practice. However, since Thai students are in collectivist cultures where individuals value social or in-group relations, they are accustomed to learning about how to do more than how to learn (Swatevacharkul, 2010). There seems to be a mismatch between the culture characteristics of Thai students and the expectations of autonomous learning approach. The findings in many studies in Thailand found that students had positive beliefs about autonomous learning, but were not ready to learn autonomously. They still believed that teachers were those to take control over their 
learning (Rukthong, 2008). Some studies indicated that learners had good perceptions on self-access learning since it offered learners independence and opportunities for individualization (Gardner, 2007; Lai, 2007). The previous findings still leave suspect whether Thai students are really ready for autonomous learning.

Since autonomous learning has been regarded as a vital aspect of learning process, especially if education aims to develop life-long learner, the concept of autonomous learning is implemented in the Thai higher educational system. In terms of English language learning, the Ministry of University Affairs in Thailand has proclaimed the curriculum standards of English Foundation Courses based on two goals. One goal specifies that students should be able to use English to help achieve personal and academic goals and to promote life-long learning. Another one emphasizes that students will use appropriate learning strategies to acquire, construct, and apply academic knowledge and to develop critical thinking skills. Learner autonomy helps learners to have self-awareness, so it is deemed as a means to enhance efficacy of language learning. Being required as goals of education included in the National Education Act, English courses offered in most of the institutions in Thailand have been redesigned to develop learners autonomy such as giving students projects to do outside the classroom, instructing students to use other learning resources, stressing fluency rather than accuracy, and conducting sessions to help students gain insight into their learning styles (Swatevacharkul, 2006). Within the framework of new curriculum, learners' autonomy has been implemented in English classrooms over a period of three years in our university.

As previously indicated, learners need to have a certain learning capacity in order to become successful autonomous learners. Thanasoulas (2000) states that certain conditions need to be set for learners to achieve autonomous language learning. For instance, learners should be trained with cognitive and metacognitive strategies. Also, they should be encouraged to be active learners by having an opportunity to define and attain goals. In this learning environment, authentic materials should be used to promote learners' motivation (Sinclaire et al, 2000). So, in designing any language courses, one of the course objectives is to provide learners with activities to tackle target language on their own.

Learners who had a higher sense of autonomy also had a greater perceived control over their learning and this was linked to academic performance (D'Ailly, 2003). Therefore, this research attempts to investigate students' beliefs in order to draw a picture of how Thai students respond to autonomous language learning. More specifically, this study placed an emphasis on gender, learning achievement, and language learning behaviors outside the class. Gender difference was a focus because female students were anecdotally better performers in English language learning (Redfield et al., 2001). Therefore, they are likely to perceive autonomous learning more positively than male students. However, there was a study conducted by Zhang \& Cui's study (2007) found no significance between males and females.

In addition, the issue of learning achievement is taken into account because Mineishi (2010) found some differences between successful and less successful learners with 
regard to their perception of learner autonomy. Less successful learners tended to prefer working together in groups to working individually. These learners tended to expect the teacher (rather than themselves) to be responsible for evaluating how much they had learnt more strongly than successful learners. Behaviors of students outside the classrooms reflect their motivation and autonomy. For instance, television, films and pop music are the main ways in which Indonesian students intentionally get exposure to English outside the school (Lamb, 2004). Bayat (2008) found relationship between autonomy perception and classroom behaviors. Understanding these behaviors can better help teachers to lead their students towards autonomous learning. It was hoped that the results of the study would provide information to teachers to understand what students believe about autonomous learning so that the courses can be adjusted to enhance learner autonomy. In addition, this study will offer some advice to practitioners who are willing to promote learner autonomy in their classes in the Asian context.

\section{Research Objectives}

The research questions guiding this study are as follows:

i. What are the students' beliefs of autonomous language learning?

ii. What are the students' language learning behaviors outside the class?

iii. Are there any relationships between students' beliefs of autonomous language learning and other factors including grade, gender, language learning behavior outside class, attitudes towards studying English?

\section{METHOD}

\section{Population and Samples}

The population of this study was 4,347 undergraduate students enrolling in a fundamental English course in the first semester of academic year of 2014 at a private university. All of them were the first-year students from nine faculties (Communication Art, Fine and Applied Arts, Law, Engineering, Humanities, Science and Technology, Accounting, Business Administration, and Economics). Prior to their study at the university level, these students were anticipated to have experience in autonomous learning at high school level due to the enforcement of the National Act which emphasized the enhancement of learner autonomy. The sample size was estimated based on G power program. A $95 \%$ of confidence level was used with a precision rate of $\pm 5 \%$. The samples should be at least 160 . Therefore, the researcher agreed to employ 160 samples in this study. They were 160 undergraduate students enrolled in a fundamental English course in the first semester of academic year of 2014 selected by Simple Random Sampling technique.

Demographic characteristics of the samples were presented in Table $1.53 .1 \%$ of the surveyed respondents were male while 46.9 were female. In terms of grade students received in EN111 course, one-third of them (27.5\%) got grade C+ while $20.6 \%$ of the respondents got grade B and $20 \%$ got grade $\mathrm{C}$. In addition, the table illustrated that 43.8\% had a positive attitude toward studying English, and $48.1 \%$ did not specify "like or dislike" while $8.1 \%$ had a negative attitude. 
Table 1

Frequency and percentage values of the samples

\begin{tabular}{lcc}
\hline & $N$ & $\%$ \\
\hline 1. Gender & & \\
- Male & 85 & 53.1 \\
- Female & 75 & 46.9 \\
\hline 2. English grade (EN011) & \\
- D & 5 & 3.1 \\
- D+ & 13 & 8.1 \\
- C & 32 & 20.0 \\
- C+ & 44 & 27.5 \\
- B & 33 & 20.6 \\
- B+ & 25 & 15.6 \\
- A & 8 & 5.0 \\
\hline 3. Attitudes toward studying English & & \\
- Positive & 70 & 43.8 \\
- Negative & 13 & 8.1 \\
- So so & 77 & 48.1 \\
\hline
\end{tabular}

\section{Research Instrument}

The data in this study came from the response of the questionnaire highlighting two major components: (a) the autonomous language learning and (b) the language learning behaviors. The questionnaire of this study was adapted from Sakai et al (2010)'s learner autonomy questionnaire. In addition to the demographic information items, there were ten items seeking to uncover students' beliefs about autonomous language learning. The respondents were asked to report their beliefs about autonomous language learning on a 5-point Likert scale, by rating the extent to which they would like to get involved in each item using the least, little, to some extent, much, the most. To investigate students' language learning behaviors outside the class, 17 items were used to collect the data. Their language learning behaviors outside the class were evaluated from how often they had done the English learning activities voluntarily since they entered the university. The replies were in a 5-point Likert scale as follows: never, seldom, sometimes, often, usually.

The questionnaire was translated into Thai language. As for the content validity, the items in the draft questionnaire were examined and corrected by three experts in the English teaching field for clarity and accuracy. The values of the congruence index for items in two parts were proper. They were between 0.67 and 1.00. The experts' comments and suggestions in terms of the wording and statement of each description were considered for modification of the questionnaire. To investigate the internal consistency among all items, the questionnaire was administered to a test group of university students and was then revised and finalized based on their feedback. The reliability of the questionnaire of this study was .96 (Cronbach Alpha), indicating a high level of internal consistency. 


\section{Data Collection}

The questionnaire was given to the samples and taken back by the researcher with the cooperation of the English teachers responsible in each class. Regarding ethical issues, the respondents in this study were voluntary. They had been informed that they could refuse to take part in the study if they felt uncomfortable. The respondents were also asked to sign a consent form that briefly described the research. They were also told that the results from the study would not affect their course grades. It took about two months for the process of collection of all questionnaires. In order to see whether students' beliefs of autonomous language learning was related to some factors or not, their English grade, gender, language learning behaviors, and attitudes toward studying English were taken to be analyzed.

\section{Data Analysis}

The data compiled by the questionnaires were analyzed using SPSS 12.0 software to answer the three proposed research questions. Research question one and two investigated the students' overall beliefs of autonomous language learning as well as their language learning behaviors outside the class. A descriptive analysis was conducted to report the mean scores and standard deviations in tables based on the following ranges: $1.00-1.50=$ very low, $1.51-2.50=$ low, $2.51-3.50=$ moderate, 3.51 $4.50=$ high, $4.51-5.00=$ very high. To answer the third research question, Pearson's Correlation coefficients were used to find out the relationship among beliefs about autonomous language learning, GPA, English grade, and language learning behaviors outside the class. Chi-square tests were conducted to find out the relationships between students' beliefs about autonomous language learning, their attitudes towards studying English, and gender. The acceptable statistical significance level was set at alpha $(\alpha)<$ 0.05 .

\section{FINDINGS}

The results shown in Table 2 indicated that the overall mean score of students' beliefs about autonomous language learning was at a high level. $(\bar{x}=3.51)$. When considering all items, it was found that six out of ten were at a high level while four items were at a moderate level. The mean scores could be arranged from the most to the least as follows: deciding topics for learning in class $(\overline{\mathrm{X}}=4.09)$, deciding the types of classroom activities $(\overline{\mathrm{x}}=4.07)$, deciding ways of assessment $(\overline{\mathrm{X}}=3.84)$, and deciding the amount, type and frequency of homework $(\overline{\mathrm{x}}=3.79)$. The lowest mean score was students' decision on the textbook and materials to be used in class $(\overline{\mathrm{x}}=2.88)$. 
Table 2

Mean and standard deviation of beliefs about autonomous language learning

\begin{tabular}{|c|c|c|c|}
\hline Statement & $\overline{\mathrm{X}}$ & S.D. & Level \\
\hline 1. Deciding your goal of study in one semester & 3.71 & .88 & high \\
\hline 2. Checking how much progress you make & 3.24 & .97 & moderate \\
\hline 3. Deciding the textbook and materials to be used in class & 2.88 & 1.04 & moderate \\
\hline 4. Deciding topics you learn in class & 4.09 & .93 & high \\
\hline 5. Deciding the pace of the lesson in one lesson & 2.97 & 1.04 & moderate \\
\hline $\begin{array}{l}\text { 6. Deciding the type of classroom activities, such as } \\
\text { individual, pair and group work }\end{array}$ & 4.07 & .80 & high \\
\hline 7. Deciding the amount, type and frequency of homework & 3.79 & .89 & high \\
\hline $\begin{array}{l}\text { 8. Deciding ways of assessment, such as attendance, writing } \\
\text { tasks and self-evaluation }\end{array}$ & 3.84 & .94 & high \\
\hline 9. Assessing your study & 2.94 & .84 & moderate \\
\hline 10. Evaluating the course & 3.61 & .87 & high \\
\hline Total & 3.51 & .51 & high \\
\hline
\end{tabular}

The student's language learning behaviors outside the class were also presented in mean and standard deviation. From Table 3, the overall mean score was at a moderate level $(\overline{\mathrm{X}}=3.27)$. Among 10 items, the third highest mean scores were "reading web pages in English" ( $\overline{\mathrm{X}}=3.87)$, "watching TV and listening to radio programs in English" ( $\overline{\mathrm{x}}=$ 3.69), and "watching English movies without subtitles" ( $\overline{\mathrm{x}}=3.69)$ respectively. These items were at a high level. The lowest mean score was no. 3. (practicing English in an English conversation school), which was at a moderate level $(\overline{\mathrm{X}}=2.67)$.

Table 3

Mean and standard deviation of language learning behaviors outside class

\begin{tabular}{lccc}
\multicolumn{1}{c}{ Statement } & $\overline{\mathrm{X}}$ & S.D. & Level \\
\hline 1. Attending an English course and seminar provided by the university & 2.83 & .89 & moderate \\
\hline $\begin{array}{l}\text { 2. Meeting with your teacher in order to discuss your work } \\
\text { English }\end{array}$ & 3.11 & .96 & moderate \\
\hline 3. Practicing English in an English conversation school & 2.67 & .97 & moderate \\
\hline 4. Learning English vocabulary words & 3.11 & 1.02 & moderate \\
\hline 5. Practicing speaking English with your friends & 3.40 & .98 & moderate \\
\hline 6. Talking to foreigners in English & 3.17 & .86 & moderate \\
\hline 7. Learning English grammar & 3.64 & .93 & high \\
\hline 8. Keeping a diary in English & 3.21 & .99 & moderate \\
\hline 9. Preparing for proficiency tests such as TOEIC, TOEFL & 2.91 & .87 & moderate \\
\hline 10. Writing e-mails in English & 3.15 & .90 & moderate \\
\hline 11. Watching English learning programs on TV & 3.27 & .96 & moderate \\
\hline 12. Reading magazines and books in English & 3.46 & .87 & moderate \\
\hline 13. Watching TV and listening to radio programs in English & 3.69 & .91 & high \\
\hline 14. Watching English movies without subtitles & 3.69 & .90 & high \\
\hline 15. Reading English newspapers & 3.01 & 1.09 & moderate \\
\hline 16. Reading web pages in English & 3.87 & .75 & high \\
\hline 17. Listening to English songs & 3.27 & .88 & moderate \\
\hline \multicolumn{1}{c}{ Total } & 3.27 & .49 & moderate \\
\hline
\end{tabular}


Pearson Correlation Coefficients were used to find out the relationships between students' English proficiency, language learning behaviors outside the class and beliefs about autonomous language learning. Hypothesis 1 predicted that there would be a positive relationship between beliefs about autonomous learning and English proficiency, and Hypothesis 2 proposed that beliefs about autonomous learning were positively related to language learning behaviors outside the class. Hypothesis 3 predicted that English proficiency would be positively related to language learning behaviors outside the class.

From Table 4, it was found that there was a positive relationship between students' beliefs about autonomous language learning and their English proficiency $(r=.220, \mathrm{P}<$ .001). This means that the higher language proficiency the students had, the higher beliefs they exhibited. However, this relationship was at a low level. Also, it was found that the students' language learning behaviors outside the class was positively related to their beliefs. This means that the students with a high level of behaviors exhibited a high level of beliefs too $(\mathrm{r}=.820, \mathrm{P}<.001)$. Therefore, Hypotheses 1 and 2 were accepted. However, Hypothesis 3 was rejected since a negative relationship was found between students' English proficiency and their language learning behaviors outside the class $(\mathrm{r}=-.196, \mathrm{P}<.05)$. In this study, it was found that the higher language proficiency the students had, the less they had learning behaviors outside class.

Table 4

The relationships between beliefs about autonomous language learning, English proficiency and language learning behaviors outside class

\begin{tabular}{lccc}
\hline Beliefs & $\begin{array}{l}\text { Proficiency } \\
\text { (grade) }\end{array}$ & $\begin{array}{l}\text { Language learning } \\
\text { behaviors outside class }\end{array}$ \\
\hline Beliefs & 1.000 & $.220^{* *}$ & $.820^{* *}$ \\
\hline Proficiency (grade) & & 1.000 & $-.196^{*}$ \\
\hline $\begin{array}{l}\text { Language learning } \\
\text { behaviors Outside class }\end{array}$ & & 1.000 \\
$* * \mathrm{P}<.001 * \mathrm{P}<.05$ & &
\end{tabular}

Prior to investigating the relationship between students' beliefs about autonomous language learning and other factors such as gender and attitudes toward learning English, data of beliefs were transformed into three groups, namely high, moderate, and low based on scores. The cut-point was determined by using Mean \pm .5 SD. The mean was 3.51, and the standard deviation was .51. So, the "high" group received 3.77 through highest values while the "intermediate" group got values between 3.26-3.76. The "low" group got lowest through 3.25 values. When the students were grouped based on their belief scores, there were 49 students with high level of beliefs, 65 students with moderate level of beliefs and 46 students with low level of beliefs.

Table 5

Students' number and percentage shown in three groups of beliefs

\begin{tabular}{lll}
\hline Group & Number & Percentage \\
\hline High & 49 & 30.6 \\
\hline Moderate & 65 & 40.6 \\
\hline Low & 46 & 28.8 \\
\hline
\end{tabular}


Hypothesis 4 proposed that gender was related to beliefs about autonomous language learning. Therefore, a Chi-Square test was employed to examine the relationship. The result found that gender was related to students' beliefs $(\chi 2=6.112, \mathrm{P}<.001)$. Female students tend to have a higher level of beliefs when they were put into three groups: high (30), moderate (25), and low (20). In contrast, male students had a moderate level of beliefs the most when organized in three groups: moderate (40), low (26), and high (19). So, this hypothesis was accepted.

Table 6

Chi-Square results for gender and beliefs about autonomous language learning

\begin{tabular}{|c|c|c|c|c|c|}
\hline \multirow[t]{2}{*}{ Gender } & \multicolumn{3}{|c|}{ Beliefs } & \multicolumn{2}{|r|}{ Chi-Sq. } \\
\hline & High & Moderate & Low & Total & \\
\hline Male & $\begin{array}{l}19 \\
(22.4)\end{array}$ & $\begin{array}{l}40 \\
(47.1)\end{array}$ & $\begin{array}{l}26 \\
(30.6)\end{array}$ & $\begin{array}{l}85 \\
(100.0)\end{array}$ & $6.112^{* *}$ \\
\hline Female & $\begin{array}{l}30 \\
(40.0)\end{array}$ & $\begin{array}{l}25 \\
(33.3)\end{array}$ & $\begin{array}{l}20 \\
(26.7)\end{array}$ & $\begin{array}{l}75 \\
(100.0)\end{array}$ & \\
\hline Total & $\begin{array}{l}49 \\
(30.6)\end{array}$ & $\begin{array}{l}65 \\
(40.6)\end{array}$ & $\begin{array}{l}46 \\
(28.8)\end{array}$ & $\begin{array}{l}160 \\
(100.0)\end{array}$ & \\
\hline
\end{tabular}

$* * \mathrm{P}<.001$

Hypothesis 5 predicted that attitudes towards studying English were related to beliefs about autonomous language learning. From Table 7, it was found that there was a relationship between students' attitudes towards studying English and their beliefs about autonomous language learning $\left(\chi^{2}=22.247, \mathrm{P}<.001\right)$. For students with a positive attitude towards studying English, the highest number (30) had moderate beliefs; 28 were in a low group; 12 exhibited in a high group. In contrast, students with negative attitudes towards studying English were in a group of high level of beliefs the most (10), followed by moderate (2) and low (1) groups. For the group of mixed feeling of positive and negative attitudes, the largest number (33) was in a moderate group while 27 were in a high group and 17 in a low group. So, this hypothesis was accepted.

Table 7

Chi-square results for attitudes toward studying English and beliefs

\begin{tabular}{|c|c|c|c|c|c|}
\hline Attitudes & & Beliefs & & & Chi-Sq. \\
\hline & High & Moderate & Low & Total & \\
\hline Positive & $\begin{array}{l}12 \\
(17.1)\end{array}$ & $\begin{array}{l}30 \\
(42.9)\end{array}$ & $\begin{array}{l}28 \\
(40.0)\end{array}$ & $\begin{array}{l}70 \\
(100.0)\end{array}$ & $22.247 * *$ \\
\hline Negative & $\begin{array}{l}10 \\
(76.9)\end{array}$ & $\begin{array}{l}2 \\
(15.4)\end{array}$ & $\begin{array}{l}1 \\
(7.7)\end{array}$ & $\begin{array}{l}13 \\
(100.0)\end{array}$ & \\
\hline So so & $\begin{array}{l}27 \\
(35.1)\end{array}$ & $\begin{array}{l}33 \\
(42.9)\end{array}$ & $\begin{array}{l}17 \\
(22.1)\end{array}$ & $\begin{array}{l}77 \\
(100.0)\end{array}$ & \\
\hline Total & $\begin{array}{l}49 \\
(30.6)\end{array}$ & $\begin{array}{l}65 \\
(40.6)\end{array}$ & $\begin{array}{l}46 \\
(28.8)\end{array}$ & $\begin{array}{l}160 \\
(100.0)\end{array}$ & \\
\hline
\end{tabular}

$* * \mathrm{P}<.001$ 


\section{DISCUSSION}

There are many underlying points of interest that are worth discussing in relation to how students respond to specific questions related to learning responsibilities and their perceived behaviors outside class. In addition, all factors are found significantly related to beliefs about autonomous language learning, which can be discussed as follows:

The finding which reveals that students have a high level of overall beliefs about autonomous language learning are similar to previous studies. For instance, a study shows that the students' responses to learner autonomy are positive (Tally, 2014). In another study conducted by Joshi (2011), more than $80 \%$ learners are found to be aware of the goals and the process of learning English. A reason for this is probably because Language Institute has adjusted the curriculum to be student-centered in all courses and has provided more activities that promote students' learning autonomy for quite a period of time. Students have possibly been conditioned to be active in classrooms. Take a pair of peer review and outside the class projects as examples. These activities help to foster students' responsibility as well as to promote their collaboration and social interaction. Having a high level of beliefs suggests that students accept the new form of learning because they are given opportunities to have learning responsibilities or control their own study continually. However, it is interesting to see that the overall language learning behaviors outside the class are at a moderate level. The finding is found to be consistent with previous studies which exhibited only moderate frequency of autonomous learning behaviors outside the class (Yan, 2007). This is probably due to the fact that nowadays students' free time is spent on social media like Facebook (Jones \& Fox, 2009), so they rarely have time to do other activities outside the class to improve their English.

The result also indicates a positive relationship between beliefs about language learning autonomy and language learning behaviors outside the class. Students with high beliefs of autonomous learning have a high level of learning behaviors while students with low beliefs have a low level of learning behaviors. This result is found to be similar to many previous studies (Bayat, 2008; Cotterall, 2008; Gan, 2004; Yildirim, 2008; Yan, 2007). This is probably because students' acceptance of autonomous learning has a great impact on behaviors. If they accept that they can decide their own learning, they feel free to choose the activities that suit themselves. Organizing their learning outside the class can occur as often as they can. That is why students with high beliefs of autonomous learning seem to have additional studies conducted outside the class. The beliefs reflect the ways they choose to acquire knowledge as well as the extent of learning. Therefore, it can be concluded that higher beliefs result in more independent learning activities and better English proficiency.

Concerning correlation between English proficiency and beliefs about learning autonomy, as the significance for these two characteristics is smaller than .05 , there appears to be a statistically significant relationship. The positive relationship suggests that high proficient students tend to have higher level of beliefs about autonomous learning. This might be explained that students in this group feel motivated by the new 
form of learning. They realize the importance of choosing the topics of their own interest as well as deciding on the type of classroom activities, such as individual, pair and group work. When scores are more allocated to projects or activities, they seem to agree more because they think they can gain better scores from those activities. For high proficiency students, the more they experience autonomous learning, the more their beliefs about language learning autonomy increase. Environments in class become more interesting, active and are not boring any more. Meanwhile, it is clear from the study that low proficient students cannot much agree with the idea of the learner autonomy. This has occurred since the past decade when the English courses had been adapted to make students have more responsibility for their own learning in their high schools. In the Thai context, students whose English are not excellent expect their teachers to be well-prepared and ready to guide them in every situation. The lessons that are taught in class should be full of knowledge. In other words, they hope they can get a lot of knowledge from the teacher. The finding is found to be similar to Mineishi's work (2010) in that less successful learners tend to expect the teacher (rather than themselves) to be responsible for evaluating how much they learn more strongly than successful learners. However, the finding is not in accordance of some studies (Dafei, 2007; Zhang and $\mathrm{Li}, 2004$ ) which find that the high or low English proficiency of the students don't always imply that their learner autonomy will be high or low correspondingly.

Inconsistent with Zhang and Cui's study (2007) which found no significance between males and females, the finding in this study indicates that gender is related to beliefs about autonomous language learning. That is, female students have a higher level of beliefs than male students. This might be because female students in this university seem to have more responsibility. In most English classes, females usually pay more attention to the given tasks than males. This can be supported by the previous study which revealed that female students were anecdotally better performers in English language learning (Redfield et al., 2001). This result is found to have the same direction as described in the previous paragraph in that high proficiency students have higher level of beliefs about autonomous learning.

Another finding which is worth discussion is attitudes towards studying English. In this study, attitudes are found to be related to beliefs about autonomous language learning. Surprisingly, students with a bad attitude towards studying English are in a group of high level of beliefs the most while those with a good attitude have moderate beliefs. The finding suggests that the former does not like the traditional way of teaching practice. Meanwhile the latter tends to be strict to the old form of learning. They prefer to be dependent on teachers and are afraid to see any changes. This reflects the existence of the old way of teaching practice in the university. This is probably because cultural influences and the norms of educational practice are obstacles to promoting autonomous learning in Thailand (Sanprasert, 2010). Thai students still do not get used to having authority and being responsible for their own learning since in the past the whole teaching practice were directed by the teacher. The concept of the classroom environments organized by the teacher who always takes control of students' learning still blocks Thai students' beliefs about learner autonomy. It rather takes time to make them believe that they are controllers in the new kind of learning environments. 


\section{CONCLUSION}

Autonomy is an essential characteristic for students, especially for those who learn a language as a foreign language and do not have the opportunity to use it in the real life situations. Autonomous students know how to enhance learning environments where the target language is used. That is, they have a skill of "self-organized language learning. They usually set themselves specific goals and try to achieve them by taking opportunities both in and out of the classroom. This can lead to a better language learning and higher proficiency. To make autonomy become real, students need to understand and accept the concept of autonomous learning. In this regard, teachers play the most important role in raising the students' awareness and re-adjusting the learning approaches (Chan, 2003). Students should be encouraged to play a more active role in learning. From the start, teachers may gradually allow them to take learning responsibilities, select their own learning materials and evaluate their own learning progress. Creating autonomous learning environments is one of the ways to make students become independent learners who can further their own studies in the future (Little, 2007; Thanasoulas, 2000).

\section{REFERENCES}

Bayat, A. (2008). Relationship between autonomy perception and classroom behaviors of English language learners. Paper presented at MA TEFL $20^{\text {th }}$ Anniversary Reunion Conference at Bilkent University, Turkey.

Chan, A. (2003). Autonomous language learning: The teachers' perspectives. Teaching in Higher Education, 8(1), 33-54.

Cotterall, S. (1995). Readiness for autonomy: Investigating learner beliefs. System, 23(2), 195-205.

Dafei, D. (2007). An exploration of the relationship between learner autonomy. ASIAN EFL Journal, November, 1-23.

d'Ailly, H. (2003). Children's autonomy and perceived control in learning: A model of motivation and achievement in Taiwan. Journal of Educational Psychology, 95 (1), 84-96.

Gan, Z. (2004). Attitudes and strategies as predictors of self-directed language learning in an EFLcontext. International Journal of Applied Linguistics, 14(3), 389-411.

Gardner, D. (2007). Integrating self-access learning into an EAP course. In D. Gardner (Ed.), Learner autonomy: Integration and support (pp. 8-32). Dublin: Authentik.

Gardner, D. \& Miller, L. (1996). Tasks for independent language learning. Illinois: Teachers of English to Speakers of Other Languages, Inc.

Hedge, T. (2002). Teaching and learning in the language classroom $\left(2^{\text {nd }}\right.$ ed.) Oxford: Oxford University Press.

Ho, J. \& Crookall, D. (1995) Breaking with Chinese cultural traditions: Learner autonomy in English language teaching. System, 23 (2), 235-244. 
Holec, H. (1996). Autonomy and foreign language learning. Oxford: Pergamon.

Jones, S. \& Fox, S. (2009). Generations online in 2009. Retrieved April 14, 2011 from http://www.pewinternet.org/w/media//Files/Reports/2009/PIP_Generations_2009.pdf

Joshi, K. (2011). Learner perceptions and teacher beliefs about learner autonomy in language learning. Journal of NELTA, 16(1-2), 13-29.

Lai, M. (2007). The influence of learner motivation on developing autonomous learning in an English-for-specific-purposes course. Master's thesis, The University of Hong Kong, Hong Kong.

Lamb, M. (2004). Integrative motivation in a globalizing world. System 32 (1), 3-19.

Lamb, M. (2004). It depends on the students themselves: Independent language learning at an Indonesian State School. Language, Culture, and Curriculum, 17(3), 229-245.

Lee, I. (1998). Supporting greater autonomy in language learning. ELT Journal, 52(4), 282-289.

Little, D. (2007). Learner autonomy. Dublin, Authentik.

Littlewood, W. (1996). Autonomy: An autonomy and framework. System, 24(4), 427-435.

Mineishi, M.(2010). East Asian EFL learners' autonomous learning, learner perception on autonomy and portfolio development: In the case of educational contexts in Japan. International Journal of Arts and Sciences, 3 (17): 234-241.

Redfield, M., Bundy, D., \& Nuefer, R. (2001). Are there gender differences in English proficiency: Looking at non English majors. Osaka Keidai Ronshu, 52(2), 215-223.

Rukthong, A. (2008). Readiness for autonomous language learning: Thai university learners' beliefs about EFL learning and use of learning strategies. Master's Degree Thesis, Mahidol University.

Sakai, S., Chu, M. , Takagi, A., \& Lee, S. (2008). Teachers' roles in developing learner autonomy in the East Asian Region. The Journal of ASIA TEFL, 5(1), 93-117.

Sakai, S., Takagi, A., \& Chu, M. (2010). Promoting learner autonomy: Student perceptions of responsibilities in a language classroom in East Asia. Educational Perspectives, 9(1-2), 12-27.

Sanprasert, N. (2010). The application of a course management system to enhance autonomy in learning English as a foreign language. System, 38, 109-123.

Sinclaire, B., McGrath, I., \& Lamb, T. (2000). Language learner autonomy: Some fundamental considerations revisited. Innovation in Language Learning and Teaching. l(1), 14-29.

Smith, R. (2008). Learner autonomy (Key concepts in ELT). ELT Journal, 62 (4), 395 397. 
Swatevacharkul, R. (2006). The effects of degrees of support for learner independence through web-based instruction on English reading comprehension of second year. Doctoral dissertation, Chulalongkorn University.

Swatevacharkul, R. (2010). An investigation on readiness for learner autonomy, approaches to learning of tertiary students and the roles of English language teachers in enhancing learner autonomy in higher education. Research Report, Dhurakij Pundit University.

Tally, P. (2014). Students' responses to learner autonomy in Taiwan: An investigation into learners' beliefs. International Journal of Humanities and Social Sciences, 4(4), Special Issue, 24-34.

Thanasoulas, D. (2000). What is learner autonomy and how can it be fostered? The Internet TESL Journal, 6(11). Retrieved October 12, 2006 from <http://iteslj.org/ Articles/Thanasoulas-Autonomy.html>

Yan, G. (2007). Autonomous English learning among postgraduate EFL learners in China: A study of attitudes and behaviours. The Journal of Asia TEFL,4(3), pp. 47-70.

Yildirim, O. (2012). A study on a group of Indian English as a second language learners' perceptions of autonomous learning. Turkish Online Journal of Qualitative Inquiry, 3(2), 18-29.

Zhang, X. \& Cui, G. (2010). Learning beliefs of distance foreign language learners in China: A survey study. System, 38, 30-40.

\section{Turkish Abstract \\ Lisans Öğrencilerinin Bağımsız Dil Öğrenimi Konusundaki İnançları Üzerine Bir İnceleme}

Öğrenen bağımsızlığının kavramı artık dil öğrenme alanında önemli bir role sahiptir. Bu durum öğrenenleri kendi öğrenmelerine yönelten yeni bir yol gösterir. Bu çalışma lisans öğrencilerinin üniversite ortamında bağımsız dil öğrenimi hakkındaki inançlarını ve öğrencilerin bu konudaki inançlarıyla ilişkili faktörleri incelemeyi amaçlamaktadır. Verileri elde etmek için özel bir üniversitede kurallı bir ingilizce kursuna devam eden birinci sınıf öğrencilerine 5 Faktörlü Kişilik Ölçeği Anketi uygulanmıştır. Bulgular dil öğrenme davranışları sınıf dışında orta seviyede olan öğrencilerin bağımsız dil öğrenimi konusundaki inançlarının yüksek seviyede olduğunu göstermiştir. Ayrıca bağımsız dil öğrenimi inançları ve ingilizcede yeterlik, cinsiyet, İngilizce çalışmaya karşı tutum, ve sınıf dışında İngilizce öğrenme davranışı gibi kapsayan bütün faktörler arasında ilişki bulunmuştur. Bulgular öğretmen ve öğrenciler arasında deneyimlerin paylaşıldığ öğrenme ortamlarına ihtiyaç duyulduğuna dikkat çekmektedir.

Anahtar Kelimeler: bağımsız öğrenme, dil öğrenimi, öğrenme bağımsızlığı, inanç, lisans öğrencileri 


\section{French Abstract \\ Une Enquête des Croyances d'Étudiants En licence d'Apprentissage des langues Autonome}

Le concept d'autonomie d'apprenant joue maintenant un rôle important dans le domaine d'apprentissage des langues. Un accent est mis la nouvelle forme d'apprentissage qui permet aux apprenants. Cette étude a eu pour but d'examiner comment des étudiants en licence ont cru de l'apprentissage des langues autonome en arrangement d'université et découvrir si quelques facteurs ont été liés à leurs croyances. Un questionnaire d'échelle de Likert à 5 points a été employé pour rassembler des données des étudiants de première année prenant un cours d'anglais fondamental dans une université privée. Les conclusions ont révélé qu'en moyenne, les étudiants avaient un haut niveau de croyances de l'apprentissage des langues autonome tandis que les comportements d'apprentissage des langues à l'extérieur de la classe étaient à un niveau modéré. Les relations ont été trouvées entre les croyances d'apprentissage des langues autonome et tous les facteurs comprenant la compétence anglaise, le genre, des attitudes vers l'étude de l'anglais et des comportements d'apprentissage des langues à l'extérieur de la classe. Les découvertes mettent en evidence le besoin d'augmenter des environnements apprenants où les responsabilités sont partagées entre des professeurs et des étudiants.

Mots Clés: en apprenant autonomie, apprentissage des langues, apprentissage autonome, croyance, étudiants en licence

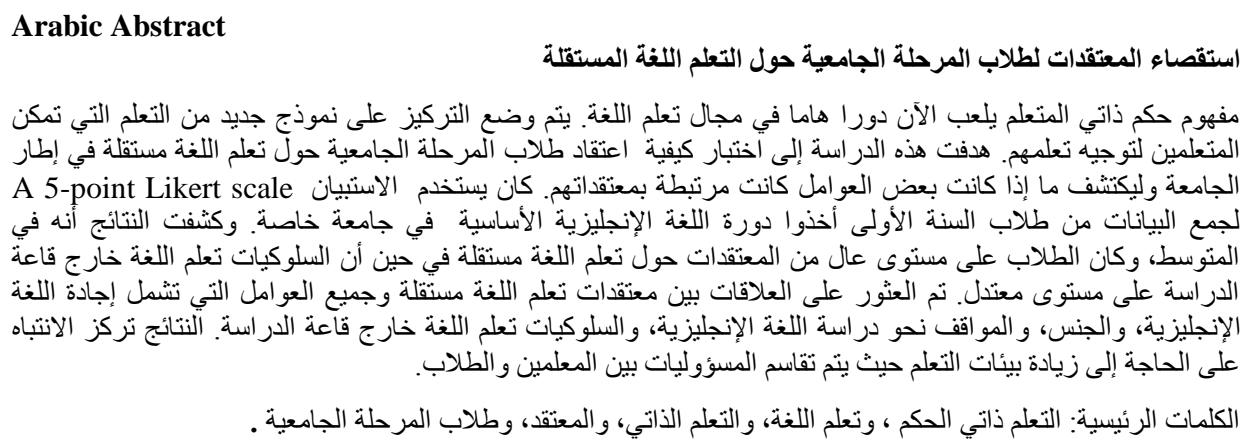

\section{German Abstract \\ Eine Untersuchung des Glaubens der Undergraduate Students über autonomes Sprachenlernen}

Das Konzept der Autonomie der Lernenden spielt heute eine wichtige Rolle im Sprachenlernen. Ein Schwerpunkt liegt auf der neuen Form des Lernens, die es Lernenden ermöglicht, ihr eigenes Lernen zu lenken. Diese Studie zielte darauf ab, zu untersuchen, wie Undergraduate Studenten über autonomes Sprachenlernen in einem Universitätsumfeld glaubten und herauszufinden, ob einige Faktoren auf ihren Glauben bezogen waren. Ein 5-Punkt-Likert-Skala Fragebogen wurde verwendet, um Daten von den ersten Jahr Studenten, die einen grundlegenden Englischkurs in einer privaten Universität zu sammelnDie Ergebnisse zeigten, dass im Durchschnitt hatten die Schüler ein hohes Maß an Glauben über autonome Sprache lernen, während Sprachlernverhalten außerhalb der Klasse waren auf einem moderaten Niveau. Die Beziehungen wurden zwischen den Überzeugungen des autonomen Sprachenlernens und allen Faktoren, die Englisch Kenntnisse, 
Geschlecht, Einstellungen zum Englisch lernen, und Sprachlernverhalten außerhalb der Klasse gefunden. Die Ergebnisse heben die Notwendigkeit hervor, die Lernumgebungen zu erhöhen, in denen Aufgaben zwischen Lehrern und Schülern aufgeteilt werden.

Schlüsselwörter: lernautonomie, sprachenlernen, autonomes lernen, glaube, studenten

\section{Malaysian Abstract \\ Suatu kajian Kepercayaan Pelajar Sarjana Muda tentang Autonomi Pembelajaran Bahasa}

Konsep autonomi pelajar kini memainkan peranan penting dalam bidang pembelajaran bahasa. Penekanan diletakkan pada bentuk baru pembelajaran yang membolehkan pelajar untuk mengarahkan pembelajaran mereka sendiri. Kajian ini bertujuan untuk mengkaji kepercayaan pelajar ijazah autonomi pembelajaran bahasa di universiti dan untuk mengetahui sama ada beberapa faktor yang berkaitan dengan kepercayaan mereka. Soal selidik likert 5-mata telah digunakan untuk mengumpul data daripada pelajar tahun pertama mengambil kursus asas Bahasa Inggeris di sebuah universiti swasta. Dapatan kajian menunjukkan bahawa secara purata, pelajar mempunyai tahap kepercayaan yang tinggi tentang autonomi pembelajaran bahasa manakala tingkah laku pembelajaran bahasa di luar kelas berada pada tahap yang sederhana. Terdapat hubungan antara kepercayaan autonomi pembelajaran bahasa dan semua faktor-faktor yang terdiri daripada penguasaan bahasa Inggeris, jantina, sikap terhadap belajar bahasa Inggeris, dan tingkah laku pembelajaran bahasa di luar kelas. Hasil kajian menyerlahkan keperluan untuk meningkatkan persekitaran pembelajaran di mana tanggungjawab dikongsi bersama antara guru dan pelajar.

Kata Kunci: autonomi pembelajaran, pembelajaran bahasa, pembelajaran autonomi, kepercayaan, pelajar ijazah sarjana muda

\section{Russian Abstract \\ Исследование Убеждений Студентов об Автономном Изучении Языка}

Концепция автономии учащегося в настоящее время играет важную роль в поле изучени языков. Акцент надевается новую форма обучения которая позволяет студентам направлять свое собственное обучение. Целью данного исследования являлось изучить, как студентов бакалавриата считали, об изучении автономного языка в университетской среде и выяснить, были ли некоторые факторы, связанный их убеждения. Вопросник Шкала Лайкерта 5-балльной был использован для сбора данных от студентов первого курса, принимая фундаментальный курс английского языка в частном университете. Результаты показали что в среднем, студенти имели высокий уровень верование о изучении автономного языка во время изучения языка поведении за пределами класса были на умеренном уровне. Отношения были найдены между верованиями обучения автономного языка и всех факторов содержащий знание английского языка, пола, отношения к изучая английского языка и изучения языка поведения за пределами класса. Находки основной момент нужда в увеличивая учебной среды, где обязанности распределяются между преподавателями и студентами.

Ключевые Слова: обучения автономия, изучение языка, автономное обучение, убеждения, студенты 